\title{
University faculty and work-related well-being: the importance of the triple work profile
}

\author{
María Vera ${ }^{1}$, Marisa Salanova ${ }^{1}$, \\ Beatriz Martín ${ }^{2}$
}

${ }^{1}$ Department of Social Psychology, Universitat Jaime I, WoNT Research Team, Castellón de la Plana

${ }^{2}$ Department of Health Psychology, Universidad Miguel Hernández, Elche

\section{Spain}

Correspondence: María Vera Perea. Universitat Jaume I. Facultad Ciencias Humanas y Sociales. Departamento Psicologia Social. Av. de Vicent Sos Baynat, s/n. 12071 Castelló de la Plana. Spain. E-mail: mvera@psi.uji.es 


\begin{abstract}
Introduction. The main aim of this study is to test whether different university faculty work profiles (i.e., teaching, research and management) relate with the experience of well-being at work (i.e., burnout, work engagement and intrinsic satisfaction).

Method. Hypotheses were tested through a K-means cluster, ANOVA, and confirmatory factor analysis in a sample of 170 Spanish university faculty members.

Results. The results show the existence of four work patterns in university faculty which take into account their triple work profile (i.e., teaching cluster, research cluster, management cluster and teaching and research cluster). Moreover, ANOVA analyses indicate that there are significant differences in absorption and intrinsic satisfaction, depending on the cluster they belong to. So far, the research cluster offers the lowest value in burnout and the highest value in engagement and intrinsic satisfaction. In contrast, the management cluster presents the highest value in burnout, and the lowest in engagement and intrinsic satisfaction. Finally, the confirmatory factor analyses showed that burnout consists of the four expected dimensions (i.e., exhaustion, cynicism, depersonalization and lack of professional efficacy).
\end{abstract}

Discussion and Conclusions. University faculty members whose work profile is predominated by research tasks are the ones who enjoy better levels of well-being, while faculty whose work profile is predominated by management tasks suffer the lowest degrees of well-being.

Keywords: University faculty, well-being, and satisfaction

Received: 11/26/09 Initial Acceptance: 05/25/10 Definitive Acceptance: 06/02/10 


\section{Profesorado universitario y su bienestar laboral: la importancia del triple perfil laboral}

\section{Resumen}

Introducción. El principal objetivo de este estudio es comprobar si los diferentes perfiles laborales de los profesores universitarios (docente, investigador y gestor) se relacionan con la experiencia de bienestar en el trabajo (burnout, engagement y satisfacción intrínseca).

Método. Las hipótesis se pusieron a prueba mediante análisis cluster, ANOVA y análisis factorial confirmatorio en una muestra de 170 profesores universitarios españoles.

Resultados. Los resultados muestran la existencia de cuatro patrones laborales en los profesores universitarios que tienen en cuenta el triple perfil laboral (docencia, investigación, gestión y docencia e investigación). Por otra parte, los análisis de varianza indican que hay diferencias significativas en la absorción y en la satisfacción intrínseca, dependiendo del patrón laboral, de forma que aquellos profesores que pertenecen al patrón laboral de investigación, tienen los valores más altos en engagement y motivación intrínseca mientras que aquellos profesores que pertenecen al patrón laboral de gestión, tienen los valores más altos de burnout. Finalmente, el análisis factorial confirmatorio muestra que burnout consta de cuatro dimensiones (agotamiento, despersonalización, cinismo y falta de eficacia profesional).

Discusión y Conclusión. Aquellos profesores universitarios en cuyo patrón laboral predomina la investigación son los que gozan de mejor bienestar, mientras que los que peor bienestar sufren son aquellos profesores universitarios en cuyo patrón laboral predomina la gestión.

Palabras Clave: Profesores universitarios, bienestar y satisfacción.

Recibido: 26/11/09 Aceptación Inicial: 25/05/10 Aceptación Definitiva: 02/06/10 


\section{Introduction}

Although traditionally, university teaching has been treated as a low stress occupation (Fisher, 1994; Hogan, Carlson, \& Dua, 2002; Winefield, 2000), things have changed in the last few decades. Nowadays, there are more and more university faculty members holding an insecure post and have a greater workload and, consequently, more research works about job stress and health among university faculty members have been conducted (Winefield, Gillespie, Dua, Hapuarachchi \& Boyd, 2003) and also it is important to consider the major changes now underway in European universities (Arco, Fernández, López, \& Heilborn, 2004; González, 2006). Moreover, we must take into account the important role played by this collective in our society, as Johnsrud (2008) stated, university faculty members, through their work, transform individual lives and improve the quality of life of the entire society, so it seems important to study this collective as well as to know any antecedent that can affect to their well-being.

Thus, this article provide an important practical contribution, since not only shows a better understanding of the work carried out by university faculty members, but also it shows how their well-being changes depending on their work pattern. Additionally, this article also makes a great theoretical contribution by testing that burnout consists of four dimensions instead of three.

Generally speaking, university faculty members spend their working hours performing different kinds of tasks which may be summarized as a triple work profile made up of teaching, research, and management tasks. And these three tasks have been already taking into account for several authors (e.g., Buela-Casal \& Sierra, 2007; Cifre, Llorens, Salanova, \& Martínez, 2003; Currie, 1996; Morrison, 1996; Vera, Martín del Río, \& Solanes, 2005). Previous research has examined the potential (im)balance among the tasks carried out by university faculty members. For example, León and Gozalo (1999) stated that there is no balance between university faculty teaching and research functions because more importance is attached to the role of researcher, while the importance of teaching tasks is played down.

Hypothesis 1: Almost all faculty members have a triple work profile, that is to say, almost all of them perform teaching, research and management tasks to a 
greater or lesser degree. Nevertheless, there are different work patterns in which one of the three tasks excels over the others in terms of time dedicated to it.

Currie (1996) claimed that the most frustrating task for university faculty members is to have to deal with institutional demands that affect their teaching and research tasks. He showed that university faculty members were losing their autonomy by spending too much time on administrative tasks. Along the same lines, a study by Court (1994) showed how university faculty members dedicated one third of their time to administrative tasks. Morrison (1996) also claimed that the pressure of teaching and management tasks were sapping the energy that university faculty members had previously applied to research tasks.

According to Chalmers (1998), university faculty members often feel frustrated because they have no time for research. This author also discussed how these members would like to have more time for research and fewer teaching hours, as well as a smaller number of administrative tasks. She finally concluded that university faculty members have increasingly more bureaucratic-administrative duties as a result of the need to obtain economic resources for research, congresses, academic exchanges, and so on. It seems that these professionals' work is no longer what it was before as it has become more submissive work with more restrictive conditions and involves working "against the clock" (Caramés, 2003).

According to Taris, Schreurs and Van Iersel-Van Silfhout (2001), research and teaching tasks entail temporary demands that cause tension, which in turn causes emotional exhaustion. Guerrero and Vicente (1999) also pointed out the obligation to make teaching and research tasks compatible as a source of strain, and even of burnout. They claimed that this happens not only because the time dedicated to one's tasks has negative influences on being able to dedicate oneself to other tasks, but also because research work evaluation is more important than teaching work evaluation. Moreover, university faculty members are becoming increasingly involved in managerial tasks that are also a source of role conflict (Moriana \& Herruzo, 2004). In addition, Lackritz (2004) concluded that feelings of burnout are more strongly related with teaching tasks than with those involved in research. 
Nonetheless, university faculty members do not have only negative experiences in their work, it also provides them with positive experiences, such as engagement, which is defined as a "positive, fulfilling, work-related state of mind that is characterized by vigor, dedication, and absorption" (Schaufeli et al., 2002, p. 72). Engagement refers to a persistent and pervasive affective-cognitive state which does not focus on any particular object, event, individual, or behavior. Vigor is characterized by high levels of energy and mental resilience while working, the willingness to invest effort in one's work, and persistence also in the face of difficulties. Dedication, on the other hand, refers to a sense of significance, enthusiasm, inspiration, pride, and challenge. The third dimension of engagement, absorption, suggests being fully concentrated and happily engrossed in one's work, whereby time passes quickly and one has difficulties with detaching oneself from work.

Finally, an important topic that it is relevant to well-being is job satisfaction. Oshagbemi $(1997,1999)$ studied the relationship between the triple work profile and job satisfaction in university faculty members. He asked university faculty about tasks that contribute to job satisfaction and found they scored high in teaching and research tasks, whereas they scored low in management tasks.

In view of these results, it may be that university faculty members with more management tasks experience more job stress (i.e., burnout), while those with more research tasks experience more work-related well-being (i.e., work engagement and intrinsic motivation). Moreover, this study stated that university faculty members with more teaching and research tasks are the ones who are more satisfied.

Hypothesis 2: University faculty members who have work patterns with more managerial tasks will show higher levels of burnout than faculty members with other work patterns

Hypothesis 3: University faculty members who have work patterns with more research tasks will show higher levels of work engagement and intrinsic job satisfaction than faculty members with other work patterns. 
With regard to university faculty members' stress, we must first consider a chronic type of stress that is referred to as job burnout. This is a syndrome with three separate dimensions: emotional exhaustion, depersonalization, and lack of professional efficacy (Maslach, 1982). According to Maslach (1993), the first refers to feelings of being emotionally overextended and depleted of one's emotional resources. The second, depersonalization, refers to a negative, cynical or excessively detached response to other people, which often includes loss of idealism. Third, lack of professional efficacy suggests a decline in feelings of competence and productivity at work.

Although these three dimensions are widely accepted, diverse empirical studies have questioned this structure composed of emotional exhaustion, depersonalization and lack of professional efficacy. On the one hand, exhaustion and cynicism constitute the "core of burnout" and leave lack of professional efficacy to one side (Browers \& Tomic, 2000; Green, Walkey, \& Taylor, 1991; Schaufeli, Salanova, González-Romá, \& Bakker, 2002; Xanthopoulou et al., 2007). On the other hand, rather than being a dimension of burnout, lack of professional efficacy is more one of its causes. Burnout could take place due to a "crisis of self-efficacy" (Bandura, 2001; Cherniss, 1993; Salanova, Bresó, \& Schaufeli, 2005). Lack of professional efficacy is an independent component of the other two components of burnout, as pointed out in the Social Cognitive Theory by Bandura (1986), which closely relates to what this author denominates "efficacy beliefs" (Salanova, Martínez, \& Lorente, 2005).

Finally, past research confirmed a four-dimensioned structure of burnout which includes emotional exhaustion, depersonalization, cynicism, and lack of professional efficacy (Salanova et al., 2005). According to these authors, it is necessary to differentiate between depersonalization and cynicism because the definition of burnout has extended to workers who are not in direct contact with recipients of the service being rendered. And depersonalization necessarily implies other people. Therefore its meaning cannot lie outside social relations. However, cynicism can appear without any social relation. Thus, Salanova et al. (2005) understood both dimensions as indicators of a "mental distance" toward work (cynicism) and toward fellow workers and the people for whom one works, i.e., clients, students, patients, etc. (depersonalization). We believe that this differentiation is necessary for university faculty members, as they may 
experience cynicism toward their work as teachers, researchers and managers, but can also suffer depersonalization toward students, coworkers or service staff.

Hypothesis 4: Burnout among our sample of university faculty members will include four dimensions: emotional exhaustion, depersonalization, cynicism, and lack professional efficacy.

Thus, the current study has three objectives. Firstly, and although most university faculty members perform teaching, research and management tasks, not all of them dedicate the same amount of time to each of these tasks. Our first objective, then, is to test whether different work profiles exist among university faculty members, taking into account the percentage of time that they dedicate to teaching, research and management. Secondly, and once we know how many work profiles there are, we shall go on to test whether different work profiles of university faculty members relate with the experience of well-being at work (i.e., burnout, work engagement, and intrinsic job satisfaction). Thirdly, we will also test the four-factor structure of job burnout (i.e., emotional exhaustion, depersonalization, cynicism, and lack of professional efficacy).

\section{Method}

\section{Participants}

The sample comprised 170 university faculty members of a Spanish university, which represents $18 \%$ of the total number of faculty members of this university $(N=955)$. Basically, Spanish university faculty may be divided into two large groups: state employees (tenured lecturers and university professors) and contract faculty (collaborating staff, part-time lecturers, etc.). In our sample population, we studied 102 contract faculty $(60 \%)$ and 68 state employees (40\%), 102 of whom were men $(60 \%)$ and 68 were women $(40 \%)$, the mean age was 39 years old $(\mathrm{SD}=8.5), 127$ were married or living with a partner (74\%), and 43 were single or divorced (26\%). A total of 87 had children (51\%) and 83 did not (49\%). The level of academic qualification of the sample was as follows: 107 were PhDs (63\%), 37 had completed the research aptitude period, that is, the first period graduates undertake before obtaining their $\mathrm{PhD}(22 \%), 23$ had a degree which involves long-cycle studies (13\%) and 3 had completed a diploma course 
involving short-cycle studies (2\%). As for work experience, 73 had 5 years' experience (43\%), 49 had between 6 and 10 years (29\%), 19 had between 11 and 15 years (12\%), 14 had between 16 and 20 years $(8 \%)$, while 13 had more than 20 years' experience $(8 \%)$.

Indeed most of the university faculty members in our sample said they had a triple work profile; specifically, only $6 \%$ of the sample had no teaching tasks, $11 \%$ had no research tasks, and finally only $16 \%$ had no management tasks. The mean amount of time spent on teaching was $50 \%(\mathrm{SD}=22.6)$, researching $32 \%(\mathrm{SD}=21.3)$ and management $18 \%(\mathrm{SD}=17.1)$.

\section{Instruments}

Burnout. Emotional exhaustion, cynicism, and lack of professional efficacy were measured with the Spanish version (Schaufeli et al., 2002) of the Maslach Burnout Inventory (MBI) General Survey (Schaufeli, Leiter, Maslach, \& Jackson, 1996). Five items measured emotional exhaustion (e.g., "I feel tired when I get up in the morning and have to face another day on the job"), four items measured cynicism (e.g., "I have lost interest in my work since I took this position"), and six items measured professional efficacy (e.g., "I can solve problems that arise in my work effectively"). Depersonalization was measured with five items (e.g., "In fact, it is of no concern to me what will happen to some people whom I must deal with in my work") from the corresponding scale of the MBI Human Services Survey (Maslach, Jackson, \& Leiter, 1996). All the items were scored on a seven-point frequency scale $(0=$ never, $6=$ always $)$. In order to obtain all the dimensions of burnout with the same sign, we reversed the scores of the professional efficacy items to obtain professional inefficacy. The Cronbach reliabilities for the scales were .85 for emotional exhaustion, .78 for cynicism, .47 for depersonalization, and .73 for lack of professional efficacy.

Work engagement was measured with the Utrecht Work Engagement Scale (Schaufeli et al., 2002). Six items measured vigor (e.g., "At work, I feel bursting with energy"), five items measured dedication (e.g., "My job inspires me") and five items measured absorption (e.g., "When I'm working, I forget everything around me”). All the items were scored on a seven-point frequency scale $(0=$ never, $6=$ always $)$. The Cronbach reliabilities for the scales were $.80, .92$, and .75 respectively. 
Job satisfaction was measured with the S20/23 Job Satisfaction Questionnaire (Meliá \& Peiró, 1989). More specifically, we focused on the fourth factor of this scale, i.e. intrinsic satisfaction, which was measured by four items (e.g., "The opportunities that your job offers you to do the things you like"). All the items were scored on a seven-point frequency scale, $(1=$ highly dissatisfied, $7=$ highly satisfied $)$. The Cronbach reliability for the total scale was .92 and the Cronbach reliabilities for the dimensions range from .76 to .89 . We focused on this factor and not on the others because we are interested in studying the satisfaction that work itself gives, that is, the opportunities that your job offers you to do what you really like.

\section{Procedure}

All university faculty members received an envelope through the university's internal mail service. This envelope contained a presentation letter, a document which they had to complete with their personal data, and a questionnaire. Both the personal data document and the questionnaire ensured confidentiality because we did not ask them for any self-identifying information. All the documents were written in Spanish.

\section{Data Analyses}

Firstly, we performed descriptive analyses, correlations and internal consistencies for each scale. Secondly, in order to establish the different work profiles, that is, to test Hypothesis 1, confirmatory K-means cluster analyses were performed and twocluster, three-cluster and four-cluster solutions were analyzed. Thirdly, once the groups had been established, we carried out ANOVA analyses in order to test Hypothesis 2 and Hypothesis 3. Finally, confirmatory factor analyses (CFA), as implemented by AMOS (Arbuckle, 1997) were used to confirm Hypothesis 4. The goodness-of-fit of the models was evaluated using absolute and relative indexes. The four absolute goodness-of-fit indexes that were calculated were: (1) the $\chi^{2}$ goodness-of-fit statistic; (2) the Goodnessof-Fit Index (GFI); (3) the Adjusted Goodness-of-Fit Index (AGFI); and (4) the Root Mean Square Error of Approximation (RMSEA). Additionally, we computed three relative indexes: (1) the Tucker-Lewis Index (TLI); (2) the Comparative Fit Index (CFI); and (3) the Incremental Fit Index (IFI). Since the distributions of the GFI and the AGFI were unknown, no statistical test or critical value was available (Jöreskog \& Sörbom, 
1986). Values below .06 for the RMSEA are indicative of an acceptable fit ( $\mathrm{Hu} \&$ Bentler, 1999), whereas for the IFI a cut-off value close to .90 suggests a good fit (Hoyle, 1995). As a rule of thumb for the remaining fit indexes (TLI, CFI), values greater than .95 are considered to indicate an adequate model fit (Hu \& Bentler, 1999).

\section{Results}

\section{Descriptive Analyses}

Descriptive analyses, correlations and internal consistencies were performed for each scale. Table 1 shows the means, standard deviations and intercorrelations of the eight dimensions. As Table 1 illustrates, although all the correlations were not significant, all their items correlated significantly in the predicted direction. The same table presents the scores of the internal consistencies (Cronbach's alpha) for all the dimensions and all scores met the .70 criterion (Nunnally \& Bernstein, 1994). In all cases, except for absorption, the alpha values in our sample are higher than those obtained on the respective scale.

Table 1. Means (M), Standard Deviations (SD), Internal Consistencies (Cronbach's alpha) and Intercorrelations $(N=170)$

\begin{tabular}{lllllllllll}
\hline & $\mathrm{M}$ & $\mathrm{SD}$ & 1 & 2 & 3 & 4 & 5 & 6 & 7 & 8 \\
\hline 1. Emotional exhaustion & 2.00 & 1.18 & .86 & & & & & & \\
2. Depersonalization & 0.68 & 0.89 & .33 & .79 & & & & & \\
3. Cynicism & 1.37 & 1.25 & $.39^{* * *}$ & $.43^{* * *}$ & .83 & & & & \\
4. Lack of professional efficacy & 1.35 & 0.80 & .15 & .10 & $.40^{* * *}$ & .75 & & & \\
5. Vigor & 4.65 & 0.88 & $-.38^{* * *}$ & $-.19^{*}$ & $-.38^{* * *}$ & $-.34^{* * *}$ & .86 & & \\
6. Dedication & 4.54 & 0.96 & $-.34^{* * *}$ & $-.21^{* *}$ & $-.48^{* * *}$ & $-.46^{* * *}$ & $.63^{* * *}$ & .87 & \\
7. Absorption & 3.98 & 0.98 & -.090 & -.13 & $-.21^{* *}$ & $-.19^{*}$ &, $52^{* * *}$ & $.47^{* * *}$ & .76 \\
8. Intrinsic satisfaction & 5.35 & 0.98 & $-.45^{* * *}$ & $-.42^{* * *}$ & $-.59^{* * *}$ & $-.25^{* *}$ &, $33^{* * *}$ & $.53^{* * *}$ & $.35^{* * *}$ & .83 \\
\hline \multicolumn{1}{c}{ Note: $* p<.05, * * p<.01, * * * p<.001 ;$ Cronbach's alpha of the scales are on the diagonal. } & &
\end{tabular}

Testing the hypotheses

A K-means cluster analysis was performed to test Hypothesis 1 and two-cluster, three-cluster and four-cluster solutions were analyzed. The four-cluster solution provid- 
ed a better interpretation because the solution fitted the university faculty members' jobs. Moreover, all three tasks in the four-cluster solution were predominant in one cluster, i.e., each task uses up more than $50 \%$ of the time available. Table 2 shows the Kmeans cluster analysis, and we can see the number of university faculty members per cluster and the percentage of time dedicated to each task in each cluster. Three clusters corresponded to the triple work profile. Furthermore, one cluster shared teaching and research tasks equally. Regarding the characteristics of each cluster, we have tested whether there are differences between the university faculty members that make up each cluster with respect to sociodemographic variables. And there are only significant differences in the level of education $(F(3,166)=9.16, \mathrm{p}<0.001)$, type of job contract $(F(3,166)=9.31, \mathrm{p}<0.001)$, and work tenure $(\mathrm{F}(3,166)=3.29, \mathrm{p}<0.05)$. In this way, $\mathrm{PhD}$ university faculty members belong mainly to the research cluster, the cluster that has a greater number of contract employees is the teaching cluster, and finally those university faculty members with more years at the university belong mainly to the management cluster.

Table 2. Number of University Faculty Members per Cluster and the Percentage of Time Dedicated to each Task

\begin{tabular}{lcccc}
\hline & $\begin{array}{l}\text { Management } \\
\text { cluster }\end{array}$ & $\begin{array}{l}\text { Research } \\
\text { cluster }\end{array}$ & $\begin{array}{l}\text { Teaching } \\
\text { cluster }\end{array}$ & $\begin{array}{l}\text { Teaching and } \\
\text { research cluster }\end{array}$ \\
\hline \% of time doing teaching tasks & $33.7 \%$ & $21.7 \%$ & $78.7 \%$ & $43.7 \%$ \\
\% of time doing research tasks & $12.4 \%$ & $69.8 \%$ & $10.7 \%$ & $39.0 \%$ \\
\% of time doing management tasks & $53.9 \%$ & $8.6 \%$ & $10.6 \%$ & $17.2 \%$ \\
$n(\%)$ & $19(11.2 \%)$ & $21(12.4 \%)$ & $47(27.6 \%)$ & $83(48.8 \%)$ \\
\hline
\end{tabular}

Moreover, in order to test Hypotheses 2 and 3, ANOVA analyses were carried out to determine whether differences in burnout, engagement and intrinsic satisfaction in university faculty members are dependent on the work patterns. Membership to a particular cluster only produced significant differences in absorption $(F(3,166)=2.81, p<$ $.05, \eta 2=.048)$ and intrinsic satisfaction $(F(3,166)=3.29, \mathrm{p}<.05, \eta 2=.056)$. However, in Table 3 we can see the means of the eight dimensions in each cluster. 
Table 3. Means of the Dimensions of each Cluster

\begin{tabular}{lcccccc}
\hline & $\begin{array}{c}\text { Management } \\
\text { cluster }\end{array}$ & $\begin{array}{c}\text { Research } \\
\text { cluster }\end{array}$ & $\begin{array}{c}\text { Teaching } \\
\text { cluster }\end{array}$ & $\begin{array}{c}\text { Teaching and } \\
\text { research cluster }\end{array}$ & $\mathrm{F}$ & $\mathrm{p}$ \\
\hline Emotional exhaustion & 1.98 & 1.83 & 1.99 & 2.05 & .20 & .90 \\
Depersonalization & 0.93 & 0.89 & 0.68 & 0.58 & 1.16 & .33 \\
Cynicism & 1.84 & 1.19 & 1.30 & 1.35 & .88 & .45 \\
Professional inefficacy & 1.41 & 1.31 & 1.30 & 1.38 & .14 & .93 \\
Vigor & 4.41 & 4.61 & 4.63 & 4.72 & .47 & .71 \\
Dedication & 4.12 & 4.84 & 4.53 & 4.56 & 1.93 & .13 \\
Absorption & 3.72 & 4.41 & 3.76 & 4.05 & 2.81 & .04 \\
Intrinsic satisfaction & 4.90 & 5.73 & 5.17 & 5.45 & 3.29 & .04 \\
\hline
\end{tabular}

Figure 1 also presents the differences in burnout, engagement and satisfaction in the four clusters. This figure clearly shows how the research cluster offers the lowest value in burnout and the highest value in engagement and intrinsic satisfaction. In contrast, the management cluster presents the highest value in burnout, and the lowest in engagement and intrinsic satisfaction. Therefore, and although there are only significant differences in absorption and intrinsic satisfaction, the trend of the averages in the other variables are in line with Hypotheses 2 and 3.

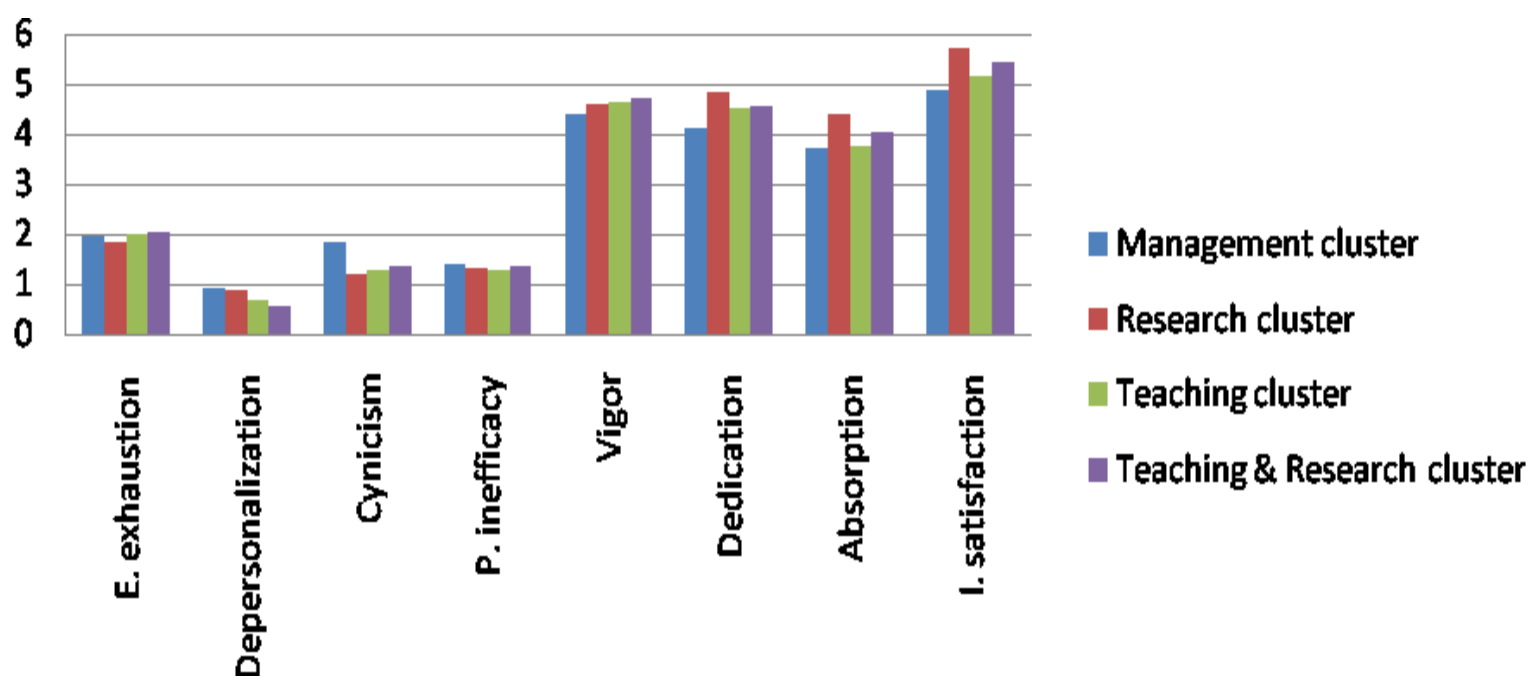

Figure 1. Burnout, engagement, and intrinsic satisfaction among the four clusters 
Finally, in order to test Hypothesis 4, CFA were used to confirm the four dimensions of burnout. We compared two alternative models: a three-factor model (M1), which assumed the traditional three dimensions of burnout, and a four-factor model (M2), which assumed four dimensions of burnout.

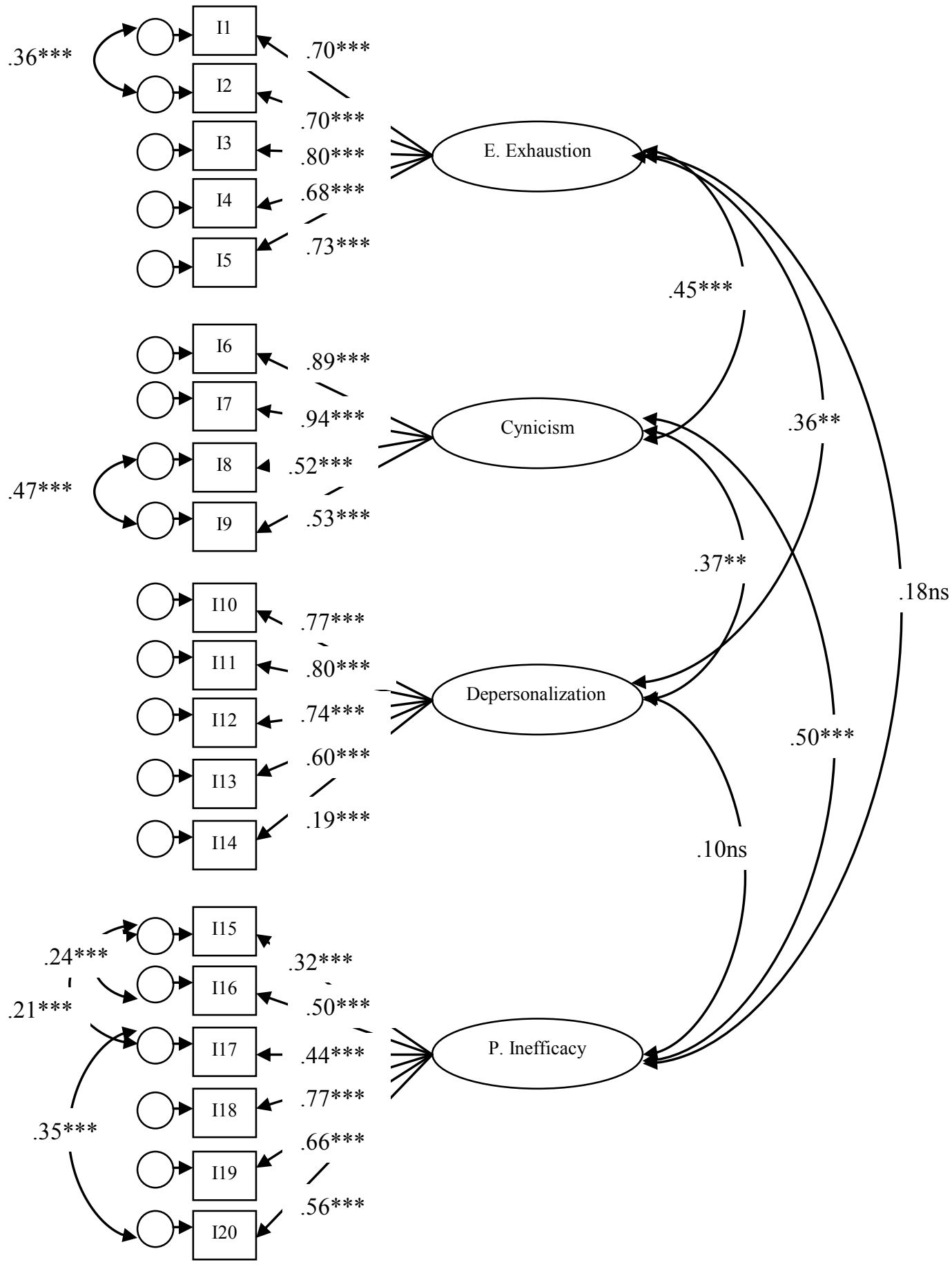

Figure 2. Confirmatory Factor Analyses $\left(\mathrm{M}_{2 \mathrm{R}}\right)$ 
As seen in Table $4, \mathrm{M}_{2}$ (four dimensions) fits better than $\mathrm{M}_{1}$ (three dimensions). On the basis of the modification indexes, the fit of the four-factor model can be improved by allowing one pair of errors to correlate from the emotional exhaustion dimension, one pair of errors to correlate from the cynicism dimension, and three pairs of errors to correlate from the professional efficacy dimension, as seen in model $\mathrm{M}_{2 \mathrm{r}}$ (see Figure 2). Finally, we can confirm Hypothesis 4 because the four-dimension model consisting of emotional exhaustion, cynicism, depersonalization, and lack of professional efficacy $\left(\mathrm{M}_{2}\right)$ fits better than a model made up of the three traditional dimensions, in which there are no differences between depersonalization and cynicism $\left(\mathrm{M}_{1}\right)$.

Table 4. Confirmatory Factor Analyses

\begin{tabular}{llllllllllll}
\hline Model & $\chi^{2}$ & df & $\chi^{2}$ /df & GFI & AGFI & RMSEA & TLI & CFI & IFI & $\Delta \chi^{2}$ & $\Delta$ df \\
\hline M1 & 557.14 & 167 & 3.34 & .72 & .64 & .12 & .67 & .71 & .72 & & \\
M2 & 353.70 & 164 & 2.16 & .82 & .77 & .08 & .84 & .86 & .86 & M2-M1=203.44*** & 3 \\
M2r & 266.09 & 159 & 1.67 & .86 & .82 & .06 & .91 & .92 & .92 & M2R-M1=291.08*** & 8 \\
& & & & & & & & & & M2R-M2=87.61*** & \\
& & & & & & & & & & & 5
\end{tabular}

Note: $\chi^{2}=$ Chi-square; $\mathrm{df}=$ degrees of freedom; $\chi^{2} / \mathrm{df}=$ ratio Chi-square / degrees of freedom; GFI = Goodness-of-Fit Index; AGFI $=$ Adjusted Goodness-of-Fit Index; RMSEA = Root Mean Square Error of Approximation; TLI = Tucker-Lewis Index; $\mathrm{CFI}=$ Comparative Fit Index; IFI $=$ Incremental Fit Index. All the $\chi^{2}$ differences between the models were statistically significant at $* * * \mathrm{p}<.001 . \mathrm{M} 1=$ Three-factor model; M2 = Four-factor model; M2r = Revised four-factor model.

\section{Discussion}

This study had three objectives. Firstly, although most university faculty members perform teaching, research and management tasks, not all of them dedicate the same amount of time to all these tasks. Our first objective was therefore to test whether different work profiles exist among university faculty members, taking into account the percentage of time that they dedicate to each of their three tasks (i.e., teaching, research and management). Secondly, and once we know how many work profiles there are, our aim is to test whether different work profiles of university faculty members relate with the experience of well-being at work (i.e., burnout, work engagement and intrinsic job satisfaction). And thirdly, we sought to confirm the four-factor structure of burnout (i.e., emotional exhaustion, depersonalization, cynicism, and lack of professional efficacy).

Thus, first, we have demonstrated that, in fact, although the triple work profile applies to most of our sample of university faculty members, the distribution of the 
three tasks within this profile is not equal in all them. Consequently, different work patterns were found to exist and were tested by a K-means cluster analysis. As already mentioned, we tested the two-cluster, three-cluster and four-cluster solutions. We also tested these solutions, and no others, because our initial aim was to confirm that there were three clusters that correspond to the triple work profile (i.e., teaching, research and management). Thus, in order to cover more possibilities, we tested two more solutions with one more cluster and one less cluster. For us, clusters make sense if there is a task in each of them that takes up more than $50 \%$ of the time spent. The four-cluster solution offers a better interpretation because this solution fits the university faculty members' job better.

Second, we tested whether these different work profiles of university faculty members are related with the experience of well-being at work (i.e., burnout, work engagement and intrinsic job satisfaction). Although differences were only significant for the absorption and intrinsic satisfaction dimensions, Figure 1 shows that there were differences and that these differences (i.e., percentage differences) are in line with what we expected in Hypotheses 2 and 3, i.e., those university faculty members whose management tasks dominate their work pattern present the highest values in burnout and the lowest in engagement and intrinsic satisfaction. In contrast, university faculty members whose research tasks dominate their work pattern present the lowest scores for burnout and the highest for engagement and intrinsic satisfaction. This also agrees with what other authors such as Caramés (2003) or Currie (1996) have postulated. Moreover, it is in line with Gozalo and León (1999), who stated that university faculty members may feel more satisfied with their work when they spend more time on research tasks, partly because the role of researcher is of great importance nowadays. Conversely, Winefield et al. (2003) proposed that stress in university faculty members has increased because they have to conduct higher quality research in order to obtain more external resources for the university. We also agree with Oshagbemi (1997) when he said that a research task is, in addition to a source of satisfaction, a cause of dissatisfaction among university faculty members, not because of the task per se, but because of the individual's inability to allocate enough time to research.

Finally, we confirmed a four-dimensional structure of burnout in our sample, composed of emotional exhaustion, depersonalization, cynicism, and lack of profes- 
sional efficacy. We firmly believe that the differentiation between depersonalization and cynicism is necessary for university faculty members since they may experience cynicism toward their work as teachers, researchers and managers, but might also experience depersonalization toward students, coworkers or service staff. Moreover, the four dimensions mentioned above have already been confirmed by Salanova et al. (2005) in two samples made up of 483 secondary-school teachers and 474 blue-collar workers.

Regarding the theoretical and practical implications, we agree with Johnsrud (2008) when she states that university faculty members are important because of the work they do, since they transform individual lives and improve the quality of life of the entire society, and hence the importance of studying this population. And we also agree with Guerrero and Vicente (1999) when they stated that it is necessary to conduct studies about university faculty members' work. According to these authors, it is important to study the multiple roles of this particular group and the discrepancies between excessive demands and the limited personal, material and institutional resources available.

However, this study is not without its limitations. The first one is the crosssectional nature of the study, although the first two objectives of the studies are essentially exploratory. In this study we described that there are different working patterns and that such patterns have different levels of well-being. Of course it is necessary to confirm these four work patterns at other universities, whether Spanish or international, and to analyze the well-being in each work pattern in other samples. Second, observations were based solely on self-reports, which might have inflated the relationships among the variables. Harman's single-factor test (Podsakoff, MacKenzie, Lee, \& Podsakoff, 2003) was therefore conducted, the results showing that one single factor could not account for the variance in the data (Delta $\chi^{2}(3)=81.97 p<.001$ ). So, common method bias is not a major drawback in this study. The third limitation is perhaps related to the sample size, since only a small percentage $(18 \%)$ of university faculty members completed the scale. Moreover, we used a convenient sample and then included all the university faculty members so that they all had the chance to respond to the scale. This method is possibly not the most effective in terms of sample collection and we could have used another type of sampling. Furthermore, the ANOVA showed that the work pattern produces significant differences in intrinsic satisfaction and absorption, but the size of the effects that were measured $\left(\eta^{2}=.056 ; \eta^{2}=.048\right)$ is low. This may be 
due to the relatively large sample size for the ANOVAs. Although not all the ANOVA values are significant, we can see clearly in Table 3 and Figure 1 that the optimal values for the university faculty members are in the cluster dominated by research tasks.

Regarding future research, we believe it is important to continue checking whether it makes sense to analyze the four dimensions of burnout in different samples. In addition, it is important to perform cluster analyses in other universities by analyzing the work situation in which there are other national and international faculty members.

\section{Final Note}

This study shows not only the reality of the triple work profile among most of the university faculty members in our sample, but also how the distribution of this triple job profile is not equal among all the faculty members, since there are four types of work patterns depending on the task which takes up the greatest amount of time. And most importantly, these members' absorption and intrinsic satisfaction depend on the work pattern. In addition, this study has confirmed that among university faculty it makes sense to talk about the four dimensions of burnout by differentiating between depersonalization and cynicism.

\section{References}

Arbuckle, J. L. (1997). Amos Users' Guide version 4.0. Chicago, IL: Smallwaters Corporation.

Arco, J. L., Fernández, F. D., López, S., \& Heilborn, V. (2004). Motivación, universidad de calidad y servicios de counseling en la universidad de Granada [Motivation, university quality and counseling services at Granada university]. Electronic Journal of Research in Educational Psychology, 2(1), 81-96.

Bandura, A. (1986). Social foundations of thought and action: A social cognitive theory. Englewood Cliffs, NJ: Prentice-Hall.

Bandura, A. (2001). Social cognitive theory: An agentic perspective. Annual Review of Psychology, 52, 1-26. 
Browers, A., \& Tomic, W. (2000). A longitudinal study of teacher burnout and perceived self-efficacy in classroom management. Teaching and Teacher Education, 16, 239-253.

Buela-Casal, G., \& Sierra, J. C. (2007). Criterios, indicadores y estándares para la acreditación de profesores titulares y catedráticos de Universidad [Criteria, indicators and standards for the accreditation of university faculty and professors]. Psicothema, 19, 537-551.

Caramés, R. (2003). Precarización y burnout del puesto de trabajo del personal docente e investigador de la universidad [Precarious and burnout in university faculty]. Revista Praxis, 2, 13-21.

Chalmers, A. (1998). Workload and stress in New Zealand universities in 1998. Wellington: New Zealand Council for Educational Research.

Cherniss, C. (1993). The role of professional self-efficacy in etiology and ameloriation of burnout. In W. B. Schaufeli, C. Maslach, and T. Marek (Eds.), Professional burnout: Recent developments in theory and research (pp. 135-149). London: Taylor \& Francis.

Cifre, E., Llorens, S., Salanova, M., \& Martínez, I. (2003). Salud psicosocial en profesores: Repercusiones para la mejora en la gestión de los recursos humanos [Psychosocial health in teachers: Implications for the improvement of management human resources]. Estudios financieros, 247, 153-168.

Court, S. (1994) Long hours, little thanks: a survey of the use of time by full-time academic and related staff in the traditional UK universities. London: Association of University Faculty.

Currie, J. (1996). The effects of globalisation on 1990s: Overworked, stressed out and demoralised. Melbourne Studies in Education, 37, 101-128.

Fisher, S. (1994). Stress in Academic Life: The Mental Assembly Line. Buckingham: Open University Press.

González, I. (2006). Dimensiones de evaluación de la calidad universitaria en el espacio europeo de educación superior [Dimensions for evaluating university quality in European higher education space]. Electronic Journal of Research in Educational Psychology, 10, 4(3), 445-468.

Gozalo, M. \& León, B. (1999). La promoción de la autoeficacia en el docente universitario [The promotion of self-efficacy in university teaching]. Revista electrónica Interuniversitaria de Formación del Profesorado, 2, 79-90. Re- 
trieved February 11, 2006, from http://www.uva.es/aufop/publica/revelfop/99v2n1.htm

Green, D. E., Walkey, F. H., \& Taylor, A. J. (1991). The three-factor structure of the Maslach Burnout Inventory. A multicultural, multinational, confirmatory study. Journal of Social Behavior and Personality, 6, 453-472.

Guerrero, E., \& Vicente, F. (1999). Una Revisión sobre las Funciones del Profesorado Universitario [A Review on the University Faculty's role]. Revista electrónica Interuniversitaria de Formación del Profesorado, 2, 571-578. Retrieved February 11, 2006 from http://www.uva.es/aufop/publica/revelfop/99-v2n1.htm.

Hogan, J. M., Carlson, J. G., \& Dua, J. (2002). Stressors and Stress Reactions Among University Personnel. International Journal of Stress Management, 9, 289310.

Hoyle, R. H. (1995). The structural equation modeling approach: Basic concepts and fundamental issues. In R. H. Hoyle (Ed.), Structural equation modeling: Concepts, issues and applications (pp. 1-15). Thousand Oaks, CA: Sage.

Hu, L., \& Bentler, P. M. (1999). Cut off criteria for fit indexes in covariance structure analysis: Conventional criteria versus new alternatives. Structural Equation Modeling, 6, 1-55.

Johnsrud, L. K. (2008). Faculty Work: Making Our Research Matter More. The Review of Higher Education, 31, 489-504.

Jöreskog, K. G. \& Sörbom, D. (1986). LISREL user guide version VI (4th. ed.). Mooresville, IL: Scientific Software International.

Lackritz, J. R. (2004). Exploring burnout among university faculty: incident, performance, and demographic issues. Teaching and Teacher Education, 20, 713729.

León, B. \& Gozalo, M. (1999). Algunas aportaciones de la psicología de la educación que guían la docencia universitaria [Some contributions of educational psychology to guide university teaching]. Revista Electrónica Interuniversitaria de Formación del Profesorado, 2, 63-78. Retrieved February 11, 2006, from http://www.uva.es/aufop/publica/revelfop/99-v2n1.htm.

Maslach, C. (1982). Burnout: The cost of caring. New York: Prentice-Hall.

Maslach, C. (1993). Burnout: A multidimensional perspective. In W. B. Schaufeli, C. Maslach, \& T. Marek (Eds.), Professional burnout: recent developments in theory and research (pp. 19-32). Washington, DC: Taylor \& Francis. 
Maslach, C., Jackson, S. E., \& Leiter, M. (1996). Maslach Burnout Inventory: Manual (3rd ed.). Palo Alto, CA: Consulting Psychologists Press.

Meliá, J. L. \& Peiró, J. M. (1989). La medida de la satisfacción laboral en contextos organizacionales: El Cuestionario de Satisfacción S20/23 [The measurement of job satisfaction in organizational settings: The S20/23 Job Satisfaction Questionnaire]. Psicologemas, 5, 59-74.

Moriana, J. A. \& Herruzo, J. (2004). Estrés y burnout en profesores [Stress and burnout in teachers]. International Journal of Clinical and Health Psychology, 4, 597621.

Morrison, A. A. (1996). University staff research time - what gets in the way? Different Approaches: Theory and Practice in Higher Education. HERDSA Annual International Conference, Perth, Western Australia, 8-12 July. Retrieved February 5, 2006, from http://www.herdsa.org.au/confs/1996/morrison.html.

Nunnaly, J. C. \& Bernstein, I. H. (1994). Psychometric theory. New York: McGrawHill.

Oshagbemi, T. (1997). Job satisfaction and dissatisfaction in higher education. Education + Training, 9, 354-359.

Oshagbemi, T. (1999). Academics and their managers: a comparative study in job satisfaction. Personnel Review, 28, 108-123.

Podsakoff, P. M., MacKenzie, S. B., Lee, J. L., \& Podsakoff, N. P. (2003). Common method biases in behavioral research: A critical view of the literature and recommended remedies. Journal of Applied Psychology, 88, 879-903.

Salanova, M., Bresó, E., \& Schaufeli, W. (2005). Hacia un modelo espiral de las creencias de eficacia en el estudio del burnout y del engagement [Towards a spiral model of efficacy beliefs in the study of burnout and engagement]. Ansiedad y Estrés, 11, 215-231.

Salanova, M., Llorens, S., García, M., Burriel, R., Bresó, E., \& Schaufeli, W. B. (2005). Towards a Four Dimensional Model of Burnout: A Multigroup FactorAnalytic Study including Depersonalization and Cynicism. Educational and Psychological Measurement, 56, 901-931.

Salanova, M., Martínez, I., \& Lorente, L. (2005). ¿Cómo se relacionan los obstáculos y facilitadores organizacionales con el burnout docente? Un estudio longitudinal [How is the relationship between organizational obstacles and facilitators and 
teacher burnout? A longitudinal study]. Revista de Psicología del Trabajo y las Organizaciones, 21, 37-54.

Schaufeli, W. B., Salanova, M., González-Romá, V., \& Bakker, A. B (2002). The measurement of engagement and burnout: A two sample confirmatory factor analytic approach. Journal of Happiness Studies, 3, 71-92.

Schaufeli, W. B., Leiter, M. P., Maslach, C., \& Jackson, S. E. (1996). Maslach Burnout Inventory-General Survey. In C. Maslach, S. E. Jackson, \& M. P. Leiter (Eds.), The Maslach Burnout Inventory - Test manual (3rd ed., pp. 19-26). Palo Alto, CA: Consulting Psychologists Press.

Taris, T. W., Schreurs, P. J., \& Van Iersel-Van Silfhout, I. J. (2001). Job stress, job strain, and psychological withdrawal among Dutch university staff: towards a dual-process model for the effects of occupational stress. Work \& Stress, 15, 283-296.

Vera, M., Martín del Río, B., \& Solanes, A. (2005). Autoeficacia en Docentes Universitarios. [Self-efficacy in the university faculty]. III Congreso Nacional de Estudiantes de Psicología, Elche (Spain), 9-11 November.

Winefield, A. H. (2000). Stress in academe: Some recent research findings. In D. T. Kenny, J. G. Carlson, F. J. McGuigan, \& J. L. Sheppard (Eds.), Stress and health (pp. 437-446). Amsterdam: Harwood Academic Publishers.

Winefield, A. H., Gillespie, N., Dua, J., Hapuarachchi, J., \& Boyd, C. (2003). Occupational Stress in Australian University Staff: Results from a National Survey. Human Sciences Press, 10, 51-63.

Xanthopoulou, D., Bakker, A., Dollard, M., Demerouti, E., Schaufeli, W. B., Taris, T., \& Schreurs, P. (2007). When do job demands particularly predict burnout?: The moderating role of job resources. Journal of Managerial Psychology, 22, 766-786. 